\title{
Methods for Management of Soilborne Diseases in Crop Production
}

\author{
Milan Panth, Samuel C. Hassler and Fulya Baysal-Gurel * \\ Tennessee State University, Department of Agricultural and Environmental Sciences, Otis L. Floyd Nursery \\ Research Center, McMinnville, TN 37110, USA; mpanth@my.tnstate.edu (M.P.); shassler@tnstate.edu (S.C.H.) \\ * Correspondence: fbaysalg@tnstate.edu; Tel.: +1-931-815-5143; Fax: +1-931-668-3134
}

Received: 17 December 2019; Accepted: 9 January 2020; Published: 11 January 2020

\begin{abstract}
The significant problems caused by soilborne pathogens in crop production worldwide include reduced crop performance, decreased yield, and higher production costs. In many parts of the world, methyl bromide was extensively used to control these pathogens before the implementation of the Montreal Protocol - a global agreement to protect the ozone layer. The threats of soilborne disease epidemics in crop production, high cost of chemical fungicides and development of fungicide resistance, climate change, new disease outbreaks and increasing concerns regarding environmental as well as soil health are becoming increasingly evident. These necessitate the use of integrated soilborne disease management strategies for crop production. This article summarizes methods for management of soilborne diseases in crop production which includes the use of sanitation, legal methods, resistant cultivars/varieties and grafting, cropping system, soil solarization, biofumigants, soil amendments, anaerobic soil disinfestation, soil steam sterilization, soil fertility and plant nutrients, soilless culture, chemical control and biological control in a system-based approach. Different methods with their strengths and weaknesses, mode of action and interactions are discussed, concluding with a brief outline of future directions which might lead to the integration of described methods in a system-based approach for more effective management of soilborne diseases.
\end{abstract}

Keywords: crop production; integrated soilborne disease management; soilborne pathogens

\section{Introduction}

Soilborne diseases are considered a major limitation to crop production. Soilborne plant pathogens such as Rhizoctonia spp., Fusarium spp., Verticillium spp., Sclerotinia spp., Pythium spp., and Phytophthora spp. can cause $50 \%-75 \%$ yield loss for many crops such as wheat, cotton, maize, vegetables, fruit and ornamentals as reported to date [1-3]. In the United States, soilborne plant pathogens are responsible for about $90 \%$ of the 2000 major diseases of the principal crops [1,4]. They often survive for long periods in host plant debris, soil organic matter, free-living organisms or resistant structures like microsclerotia, sclerotia, chlamydospore or oospores. Accurate diagnosis of a particular disease is difficult due to the similarity in symptoms such as seedling damping-off, root blackening, root rot, stunting, wilting, yellowing, bark cracking and twig or branch dieback which in turn makes the disease harder to manage [5]. To control these disease outbreaks, conventional synthetic chemical fungicides and fumigants need to be applied at regular intervals throughout the growing season of the crop. However, it should be noted that there are evident issues with the use of synthetic fungicides which include ecological disturbance, human health hazards, damage to aquatic ecosystems, reduction of beneficial microorganisms in the soil and even ozone layer depletion. In many parts of the world, methyl bromide was extensively used to control those pathogens before the implementation of the Montreal Protocol in 1986 - an international treaty to protect the ozone layer [6] which also agreed to phase down the production and use of hydrofluorocarbons in 2016 with the Kigali amendment. With 
the increasing environmental constraints, alternatives to broad-spectrum fungicides and fumigants are being developed and put into use. However, these alternative disease-management methods either have inconsistent results [7] or are less effective than methyl bromide [8].

The use of fungicides against soilborne plant pathogens can help to manage some diseases, in contrast, frequent and indiscriminate use can increase environmental and health concerns and lead to development of fungicide resistance [9]. Some environment-friendly approaches such as the use of crop rotation, soil solarization, anaerobic soil disinfestation, soil steam sterilization, biofumigants, resistant cultivars/varieties or grafted plants and biocontrol products have been developed to control soilborne diseases while maintaining the environment. Studies on disease suppressive soils have led to the development and adoption of new approaches [10-15], and to a better understanding of soil microbial community responses [11,16-19]. These advances show that active management of soil microbial communities could be an effective method to develop natural suppression of soilborne plant pathogens [20]. As soil comprises a full ecosystem including many fungi, bacteria, insects, nematodes and other microbes, it is very important to understand those interactions to develop a soil health management strategy instead of focusing on individual disease causing species [21]. This review paper seeks to summarize the current methodology used for management of soilborne diseases including sanitation, legal methods, resistant cultivars/varieties and grafting, cropping system, soil solarization, biofumigants, soil amendments, anaerobic soil disinfestation, soil steam sterilization, soil fertility and plant nutrients, soilless culture, chemical control and biological control in a system based approach.

\section{Soilborne Disease Management Methods}

\subsection{Sanitation}

With the resting structures like chlamydospores, microsclerotia, oospores or sclerotia and basic reproductive systems, soilborne plant pathogens can survive in the soil for a very long time, even in the absence of a living host or plant debris and soil organic matter. Therefore, it becomes very important to remove the plant debris away from growing areas whenever possible or accelerate residue breakdown. Sanitation includes any sort of activities which are aimed to prevent the spread of pathogens by removing diseased and infected plant parts, decontamination of tools and equipment and washing hands. Weeds and volunteer plants should be destroyed as they can function as a host for pathogens as well as increase the relative humidity around the crop canopy, creating an environment in which many pathogens thrive. Plowing under infected crop debris is also a good sanitation measure to control certain soilborne plant pathogens as tillage can expose the infected plant materials to the direct sunlight, which can kill some plant pathogens. The diseased plants and the immediate soil around its canopy should be removed to reduce the further spread of some diseases like lettuce drop or white mold caused by S. sclerotiorum [22]. Tools that are used should be disinfected or cleaned at a minimum, when moving equipment between different plants or fields using different methods such as heat treatment, ultraviolet (UV) treatment and chlorine treatment. Thus, preventative measures should be adopted to avoid pathogen contamination. Field sanitation in combination with many other methods, can yield a desirable outcome. This is the first step for the management of soilborne diseases in an integrated system.

\subsection{Legal Methods}

Legal methods can be defined as any regulation, law or quarantine that prevents the movement of a disease-causing agent by country, region, state, or county. The long-distance transfer of soilborne plant pathogens may occur through packing materials, containers, plant material, seeds, plant products, soil, animals or even humans. Introduced pathogens can remain below the detection threshold for many years, only to emerge later with destructive intensity [23]. Some specific studies conducted in Europe and North America have clearly shown that the plant trade is one of the main pathways for the dispersal of Phytophthora species (P. ramorum, P. drechsleri, P. hedraiandra, P. hibernalis, P. nicotianae, 
P. palmivora and P. syringae) in ornamental plants [24,25]. Sikes and his colleagues reported the increase in arrival rate of fungal plant pathogens with the increasing trade in New Zealand over the years [26]. As international trade and travel have risen prominently over the last five decades [27,28], the arrival and establishment of non-native species are also increasing [29-33]. Most of the developing countries, either due to lack of technology or skilled manpower or both, suffer more from the diseases that are being imported with the seeds and plant materials. The regulatory measures are constantly being updated and enforced. However, even with quarantines, there is always a risk of additional soilborne plant pathogen introductions.

\subsection{Resistant Cultivars/Varieties and Grafting}

One effective tool in disease prevention is the use of resistant cultivars/varieties. At the same time, the development of resistant cultivars/varieties through plant breeding is an industrious and time-consuming effort to combine resistance and desired commercial traits [34]. Also, there is not any one plant cultivar/variety that is completely resistant to all disease threats. The cultivars/varieties having the marking of resistance against a disease have higher level of resistance than those labeled tolerant [22].

Control of soilborne pathogens in tomatoes such as F. oxysporum f. sp. lycopersici, F. oxysporum $\mathrm{f}$. sp. radicis-lycopersici, Pyrenochaeta lycopersici and Meloidogyne spp., has been successful using resistant rootstocks in grafted plants [2]. Davis and his colleagues found that the resistant clones of potato remained resistant against Verticillium wilt for five years of continuous cropping [35]. Conventional breeding is an essential tool for crop improvement, while this is also true that it requires much skill and effort. So, alteration of genetic material by biotechnology is more promising [36]. A better understanding of host-microbe interaction can play a very good role in the use of genetic engineering to create disease resistance. For instance, we can introduce those genes into plants which encode proteins that are capable of degrading mycotoxins $[37,38]$ or suppressing the activity of cell wall-degrading enzymes $[38,39]$. Use of genetic engineering in crop improvement programs is intensively researched, yet, acceptance of these tools by the general public is still lagging.

Although grafting is more popular in fruit and nut production, its use in high-value vegetable crop is increasing. Grafting of susceptible scions on the compatible disease-resistant rootstocks is an important strategy for the management of soilborne plant pathogens. Some soilborne diseases such as bacterial wilt and root-knot nematode of solanaceous vegetables and Fusarium wilt of cucurbits are managed by grafting techniques $[40,41]$. Grafting has been commonly used to manage Verticillium wilt in solanaceous vegetables. As the biology of the pathogen, Fusarium, is well known and the rootstocks resistant to Fusarium are widely available, the risk of Fusarium can be managed through grafting. Along with the achievement of disease resistance and tolerance, grafting may also increase tolerance to abiotic stresses, efficient water and nutrient utilization, better growth and development, improve crop yield and quality and yield stability [34,42-45]. In spite of the huge advantages, grafting can create incompatibility between scion and stock causing many physiological disorders, and reduction in quality, yield and alteration of flowering patterns. For example, Stitger reported transport blocking of photosynthates from scion to rootstock when melon was grafted on Cucurbita ficifolia (Bouché) due to incompatibility [46]. Other studies also demonstrated that, fruit quality decreased in grafted tomato plants compared to the non-grafted tomato [47,48]. However, inducing the differentiation of the vascular tissues at rapid rate using auxin related compounds is a promising research area to focus. Thus, as an important measure to manage the soilborne disease, we can use the resistant cultivars and grafting method as an integrated way to make it more effective and focus our future research on grafting and resistant cultivars/varieties to address the issue.

\subsection{Cropping System}

Mixed cropping, intercropping and crop rotation are important practices that are widely emphasized around the world to avoid the inoculum buildup of soilborne pathogens. When the same 
crop is grown in a field year after year, development and persistence of soilborne pathogens is almost certain. Crop rotation is also associated with enhanced soil fertility, improvement in soil chemical and physical properties, good soil water management and soil erosion control [2,24]. Although crop rotation is a valuable method of plant disease management, it is less effective against soilborne pathogens that have a wide host range or produce long-living survival structures like sclerotia, oospores or chlamydospores [49]. In many cases, cover crops are only effective against pathogens which are surviving in soil or residing on crop residue but not against the wind-blown or vectored, thus it is recommended to use the combination of disease-free planting materials and crop rotation [50]. Rather than considering individual crops, rotation based on the plant family is a better approach for many soilborne diseases. For example, tomato should be rotated with legumes, cole crops, or lettuce but not within the Solanaceae family (eggplant, chili, potato etc.) to reduce Fusarium wilt (F. oxysporum). Crop sequences like oat-potato, annual ryegrass-potato or clover-potato reduces $R$. solani inoculum levels in the soil and suppresses disease development [51]. Larkin and his colleagues demonstrated reduction in Rhizoctonia canker and black scurf through the rotation cycles of barley and clover, in comparison with the continuous potato [52]. But due to limited availability of crops for crop rotation, it is always difficult to control some of the diseases. Plant pathogens like S. sclerotiorum are difficult to manage due to the broad host range and its production of durable survival structures (sclerotia) that can persist for long period between hosts. Rotation among plant families is not effective for all soilborne pathogens. Both being susceptible to Phytophthora blight (P. capsici), peppers cannot be rotated with cucurbits. Great caution should be taken when selecting crops for crop rotation. Crops susceptible to the same anastomosis group of Rhizoctinia should not be rotated for at least three years, which is also true for control of black rot (Ceratocystis fimbriata), stem rot (F. oxysporum) and scurf (Monilochaetes infuscans) disease of sweet potato [53]. However, not all of the strains of Rhizoctonia affects potato, for example, anastomosis group 3 (AG3) is primarily a pathogen of potato (R. solani is actually a species complex which is subdivided in 13 different anastomosis groups (AG1-AG13) based on the hyphal fusion reaction) [54]. Some of the leguminous crops like clover, vetch, pea can also be used in crop rotation, which can add the biomass in the field, thus increasing beneficial microbial population, and also adding nitrogen to the soil. By contrast, Kobayashi-Leonel and her colleagues reported that the cover crops like alfalfa, red clover and pea can harbor soilborne pathogen like F. virguiliforme (soybean sudden death). Thus, careful selection of crops for rotation is recommended [55]. Moreover, Hiddink and his collegues reported the null effect of mixed cropping of soil with brussels sprouts and barley or with triticale and white clover [56]. With the wide host range of certain plant pathogens or production of durable resting structures to avoid harsh environmental conditions, modifications of the cropping system alone may not be an efficient method to manage many soilborne pathogens. The future research focusing on suitable agronomic practices integrated with promising soilborne disease methods, is aspired by the growers.

\subsection{Soil Solarization}

Soil solarization is an environment-friendly, pre-planting method of using solar energy to control fungi, bacteria, oomycetes, nematodes, insects, and weed seeds in the soil. It can be performed by placing transparent plastic sheets over the production bed after sufficient irrigation. The plastic sheet then allows the solar radiation to be trapped inside to heat the upper layers of soil surface [2,22]. Soil solarization is a climate-dependent measure so, it should be adapted to those regions and seasons [2] which allow abundant sunshine and high temperature [14,22]. However, effective application cannot be expected in the northern latitudes of North America, Canada and Europe, and areas with low light intensity. Through direct thermal destruction, soil solarization changes microbial population of the soil and can eliminate most of the pests. This process, when performed during the hot summer months, can increase the soil temperature to a level which kills many important soilborne pathogens like $V$. dahliae, certain Fusarium spp., Sclerotinia spp., Agrobacterium tumefaciens, Streptomyces scabies, and nematodes, in addition to controlling many weeds $[22,57,58]$. As soil solarization is not only dependent on climate 
factors, it also depends on mulching material, soil temperature, soil moisture and duration of heating. For example, use of ethylene-vinyl acetate plastics has increased the soil temperature compared to polyethylene films [59]. In contrast, considering the costly disposal of these materials, biodegradable materials such as paraffin-wax emulsion mulch would be good choice as a mulching material $[60,61]$. A few researchers also proposed the use of irrigation before solarization to be able to balance the soil thermal equilibrium, on the other hand, more research is needed to conclude the relationship between soil moisture and temperature to determine the effect of solarization $[62,63]$. Soil solarization can be a cost-effective method for management of soilborne diseases, especially for organic growers as it does not demand any special skill and technology. Even though soil solarization is a cost-effective method, it takes a relatively long period of time to work and is solely dependent upon climatic conditions, therefore its application in crop production is limited. However, if applied as an integrated measure, combining the plants having allelopathic effect (Brassica cover crops and Allium species), the efficacy of soil solarization can be increased.

\subsection{Biofumigants}

The crops in the family Brassicaceae, such as cabbage, broccoli, kale, turnip, radish, canola, cauliflower, rapeseed and various mustards contain substances which can be effectively used to control soilborne pathogens and pests. A sulfur compound, glucosinolate, is produced by Brassica crops and releases biologically active products upon hydrolysis such as isothiocyanates (ITC), which are found to be toxic to many soil organisms such as P. nicotianae and R. solani. This method has been used effectively against soilborne pathogens and is widely known as biofumigation [64-66]. These biochemical compounds either directly control the growth of harmful soilborne plant pathogens or create a favorable environment for beneficial ones; which in turn increases the competition among the microorganisms resulting in an antagonistic relationship among the microorganisms. Plants belonging to Alliaceae, like onion and garlic, also contain molecules which can be used to control soilborne pathogens. Auger and his colleagues reported that the use of crushed Allium spp. containing thiosulfinates and disulfides have the same spectrum of pesticidal activity as methyl bromide [67], which could be used in agriculture as an effective integrated disease-management tool [68]. Used as a green manure, broccoli (B. oleracea), has reduced the number of $S$. minor sclerotia in soil $[22,69]$. Ramirez-Villapudua and Munnecke found that cabbage yellows (F. oxysporum f.sp. conglutinans) was eliminated when grown in plots with cabbage residues incorporated prior to soil solarization [70]. Baysal-Gurel and her colleagues also reported the effective control of R. solani and P. nicotianae in the woody ornamentals using Brassica cover crops [15]. The fungitoxic gases, probably sulfur-containing volatiles, were trapped underneath the plastic sheet and contributed to the reduction of the fungal pathogen population [71-73]. Soil type and soil environment may affect ITC release; for example, higher clay or peat content reduces the efficacy of ITC $[15,74,75]$. Although use of biofumigant cover crops has great potential, they can perform inconsistently and may actually increase disease severity and cause phytotoxicity. For instance, Kwerepe and Labuschagne reported that the use of Brassica residues at higher rate causing phytotoxicity to groundnut [76]. Care should be taken while using biofumigant cover crops as well as when considering planting time of the subsequent crop. For example, winter cover crop can be stressed, and growth can be limited due to sub-optimal climatic conditions, which can result in higher numbers of pathogens. It should also be noted that the Brassica cover crops can reduce the nutrient availability and harbor other pests. Now, the researchers are trying to investigate the dynamics of biofumigation by different means. For example, Clarkson and his colleagues explained the different ways of using biofumigation like intercropping and rotation with biofumigant cover crop, incorporation of biofumigant cover crops into the soil, use of processed biofumigants, and as green manure or trap crops [77]. Also, the addition of myrosinase, an endogenous enzyme to hydrolyse glycosinolates to ITC, was found to increase the microbial activity in the soil along with biofumigant crops [78]. The strengths and weaknesses of biofumigants should be apparent 
from the proceeding text; in order to be effective, biofumigation should be applied in conjunction with other approaches found within the scope of integrated soilborne disease management.

\subsection{Soil Amendments}

Organic amendments to the soil are traditionally used for improving soil conditions and crop productivity, but they can also aid in suppressing soilborne pathogens. Composts and liquids enriched with essential oils, phenols, organic acids and many other biocidal compounds from herbs could be effective against soilborne diseases [79], although the use of these soil amendments is rare $[80,81]$. Organic manures made up of organic wastes, composts and peats, have been proposed to control soilborne diseases and pests. R. solani, Thielaviopsis basicola, V. dahliae, species of Fusarium, Phytophthora, Pythium and Sclerotium are found to be managed effectively by the application of organic amendments $[82,83]$. These organic amendments not only improve soil structure and increase water holding capacity, they also support other beneficial microorganisms which help to suppress soilborne pathogens. The increase in activity of microorganisms in the soil creates competition, which may lead to effective suppression of harmful soilborne pathogens. The use of compost extract containing huge populations of microbiota, e.g., Rhizobacteria, Trichoderma and Pseudomonas species, can enhance crop production and produce plant growth regulators and chemicals such as phenols or tannins which may have an antagonistic effect on soilborne pathogens [84]. Soil organic amendments also provide diversified food base, which can diversify and change the microbial population equilibrium in the soil [85] which is also explained by the recent sequencing-based research [86-88]. Even though the studies have not yet confirmed the effect of frequency of organic amendments in the soil for disease suppression [85], the recurrent addition of the organic amendments enhanced respiration and chemical properties of the soil [89]. In addition, biochar, a solid co-product of biomass decomposition, can be effectively used as an organic amendment to the soil, as a source of carbon. Research in the use of biochar has already demonstrated its importance in the soil-rhizosphere ecosystem such as improvement of $\mathrm{pH}$, increase in cation exchange capacity [90]; increase in nutrient retention in light soils [91]; and promotion of beneficial microorganisms in the soil, thus improving disease suppressiveness of the soil [92]. Brtnicky and colleagues demonstrated the co-application of biochar with organic manures can change the soil properties which favors beneficial soil microorganisms [93]. Jaiswal and his colleagues demonstrated the use of biochar as an effective method to control the disease severity caused by P. aphanidermatum in cucumber seedlings [94]. Although the effect of compost and organic matter on soilborne disease suppression has been demonstrated in many studies, the efficacy of these amendments widely depends upon the amount added, type of soil, physical properties like structure and chemical properties such as cation exchange capacity, $\mathrm{pH}$, electrical conductivity of the soil. Sullivan and Miller demonstrated the use of a low rate of organic amendments to growing media to reciprocate negative growth effect and phytotoxity [95]. Some soilborne pathogens such as R. solani, are very difficult to control with the addition of organic amendments, resulting in increasing disease severity $[82,96,97]$. Kebrom and his colleagues evaluated the phytotoxity of commercially available organic amendments in the United States, which confers the need for research on the safe use of organic amendments [98]. Similarly, use of biochar at concentration above 3\% resulted either inefficacy or underirable results $[99,100]$ nessecitates further research on effective use of biochar. Efficacy of organic amendments, like compost, also depends upon the raw materials from which it is derived, process and quality of compost $[97,101]$. This opens up the wide research area where we can improve the efficacy of organic amendments by integrating it with different other means such as biofortification, soil solarization etc. For instance, biofortification of organic compost with beneficial microorganisms can also enhance the disease suppressiveness of the soil with higher efficacy and reliability [102]. Also, the addition of organic amendments followed by soil solarization can increase beneficial microbe interaction in the soil [34] with induced resistance in the host plant [103]. Thus, well balanced use of soil organic amendments together with the methods described such as soil solarization, biological antagonists can be an integrated approach for the management of soilborne pathogens. 


\subsection{Anaerobic Soil Disinfestation}

Anaerobic soil disinfestation (ASD), also known as biological soil disinfestation [104], is a process of disinfesting the soil by making it anaerobic using easily decomposable amendments such as rice bran, fresh crop residues, soybean flour and vineasses [105], covering it with plastic film, and irrigating to saturation. ASD can be applied in open field, greenhouses and even soilless systems [106]. The soil amendments used in ASD provide the substrate for rapid microbial growth. The irrigation and plastic mulch followed by soil amendment decomposition restricts the gaseous exchange between the soil and atmosphere, thus creating anaerobic decomposition of the added amendments. The anaerobic decomposition of the soil amendment allows many toxic substances to accumulate in the soil such as acetic acid, butyric acid, and other volatiles which can reduce the soilborne plant pathogens. Many soilborne plant diseases such as Fusarium wilt (F. oxysporum), southern blight (S. rolfsii), Verticillium wilt (V. dahliae), bacterial wilt (Ralstonia solanacearum) and root-knot nematodes (Meloidogyne spp.) are found to be susceptible against ASD [107]. Agrobacterium tumefaciens and P. ultimum were found to be controlled using the ASD technique $[108,109]$ and ASD can also increase the beneficial microbes in the soil, thus helping to control the harmful soilborne pathogens by creating competition. ASD is now being commercially used in California for strawberry production [110]; in Japan for melons, cut flowers and tomatoes [106]; and in the Netherlands for strawberries, asparagus and even tree nurseries [111]. New techniques need to be tested in various dynamics as ASD depends upon various factors and, for the most part, soil amendments. Shrestha and her colleagues reported the use of liquid form of amendment to be more effective to control soilborne diseases than solid form [112]. Also, the rate of amendments can influence the disease suppressiveness as low rates were significantly less effective. As ASD has already proved to be effective against many soilborne plant pathogens, this technique could be a very useful method for the growers to manage the soilborne diseases while improving the soil conditions. Research hereafter, with different elements of ASD and its integration with other methods is coveted by the growers.

\subsection{Soil Steam Sterilization}

Soil steam sterilization is a technique to sterilize the soil by using hot steam in the open field, high tunnels or greenhouses. First applied in Germany in 1888, it was the primary method for disinfecting the field prior to the arrival of soil fumigants [113]. Fungi, bacteria, weeds, a few viruses and nematodes can all be controlled using hot steam. This method involves the injection of hot water vapors in the soil using boilers and conductors. Tanaka and her colleagues observed the better control of fungal pathogens using steam than methyl bromide and chloropicrin [114]. Afek and Orenstein successfully reduced the incidence of soilborne pathogens such as S. scabies, Spongospora subterranae, Fusarium spp., R. solani, and C. coccodes in potato tubers using steam [115]. Moreover, Fennimore and his colleagues detailed the use of mobile steam applicator to improve the yield of strawberries in California [116]. Steaming the soil was found to be effective, and was comparable to methyl bromide for root-knot nematode control in cut flower production in Florida [117]. Furthermore, the length of time and temperature for disinfecting the pathogens may vary according to pathogen and type of soil. $R$. solani was eliminated by steaming trays of tobacco at $80^{\circ} \mathrm{C}$ for $30 \mathrm{~min}$ [118]. However, Minuto and his colleagues reported the elimination of F. oxysporum and $R$. solani only after $3 \mathrm{hrs}$ of steaming at $80^{\circ} \mathrm{C}$ in sandy-loam soil at $16 \mathrm{~cm}$ depth [119]. Even though there are some heat resistant spore forming fungi which can survive the high temperature, the use of steam treatment integrated with other techniques could be effective against the soilborne disease to an extent. In the similar way, steaming along with the use of exothermic chemicals such as potassium hydroxide $(\mathrm{KOH})$ or calcium oxide $(\mathrm{CaO})$ was found to be effective against tobacco mosaic virus [120]. Nonetheless, the fuel consumption, labour and time consumed to apply this technique in the field make its adoption unappealing [120]. Steam soil disinfection is more popular in greenhouses, high tunnels and container production as it is difficult to operate in the open field. Samtani and his colleagues reported the reduction of net return to the growers because of high fuel and equipment costs of this method [121,122]. This dictates the next step 
research related to steam disinfection as an integrated disease management strategy with development of easy and cost-effective tools would be pursued by growers as climate change, food insecurity and concerns about environmental health are increasing day by day.

\subsection{Soil Fertility and Plant Nutrients}

Soil fertility and chemistry including soil $\mathrm{pH}$, calcium, phosphorus and zinc levels and nitrogen form can all play a major role in the management of soilborne diseases. Soil nutrition, along with the use of fertilizers and amendments, have been shown to directly impact microbial communities. Adequate nutrition can make the plant more tolerant or resistant to diseases [50] as mineral nutrients are components of plants which regulate metabolic activity which is related with plant resistance and pathogen virulence [123]. The conditions that influence the availability of various nutrients have led to the classification of diseases by high or low $\mathrm{pH}$ and moisture- or nutrient-specific diseases [124]. In particular, Huber and Watson have discussed that the form of nitrogen available to the pathogen affects the disease severity or resistance [124]. The diseases caused by P. myriotylum, S. rolfsii, Cylindrocladium crotalariae, S. minor, R. solani and F. solani can be suppressed by calcium applications, which increases the structural integrity and resistance of middle lamella, components of cell wall, and cell membranes to the toxins produced by harmful pathogens [125]. Also, Myers and Campbell used lime to control clubroot of crucifers (Plasmodiophora brassicae) as the increase in $\mathrm{pH}$ helps in uptake of calcium [126]. In addition, Jones and his colleagues have established a direct correlation between adequate calcium levels, $\mathrm{pH}$ range and decreasing levels of Fusarium in various crops like tomatoes, cotton, melons and many ornamentals [127]. The nitrate form of nitrogen makes the root zone less acidic, though, the beneficial effect of higher $\mathrm{pH}$ is lost by using the acidifying ammonium form of nitrogen. The study of Woltz and Jones on tomato shows the use of nitrate nitrogen in the soil with higher $\mathrm{pH}$ results in better control of Fusarium wilt [128]. Woltz and Ebgelhard demonstrated that the use of nitrate nitrogen produced the lowest levels of Fusarium wilt on chrysanthemums, king asters, and carnations [129]. Potassium levels are also associated with the management of soilborne diseases in crop production. Reduced incidence of Fusarium in tomatoes with higher potassium levels was shown by Foster and Walker [130], while severity of wilt in cotton is also decreased with increasing levels of potassium $[50,131]$. The level of phosphate in the soil can also be critical to disease. It has been shown that higher rates of phosphorus increase the severity of Fusarium wilt in cotton and muskmelon $[50,127]$. Systemic acquired resistance may be involved in disease suppression which is regulated by many micronutrients. For example, manganese inhibits the aminopeptidase induction which supplies essential aminoacids for fungal growth and also, pectin methylesterase which is a fungal enzyme that degrades plant cells [132]. Similarly, toxic effect of zinc can reduce disease severity caused by P. dreschsleri $[133,134]$. Boron, an essential micronutrient, also plays role in cell wall structure and stability, nevertheless, more research related to the relationship between boron and disease resistance or tolerance is needed. Several other elements such as lithium, sodium, cadmium, aluminium and mercury may also have role in host plant relationship [134], which necessitates the further research. Disease resistance is primarily genetically controlled; however, it can be modulated by physiological and biochemical processes which are associated with nutrient level. Therefore, the proper management of nutrients, along with other integrated measures to control the diseases, aids in keeping the disease under the threshold level.

\subsection{Soilless Culture}

Soil is the most abundant growing medium which provides anchorage, nutrients, water and air to the root system of the plants. At the same time, due to the presence of disease-causing organisms and nematodes, degradation of soil due to erosion and accumulation of salts can cause plant growth to be limited. Planting in soilless culture is an effective and environment-friendly alternative to soil systems and can replace methyl bromide [135]. Soilless cropping can also improve water-use efficiency and nutrient management. Although hydroponics is primarily limited to greenhouses, it is expected 
to increase. Neshev has stated that the area in Bulgaria on artificial substrate under greenhouse increases by 10-20 ha every year [136]. The higher yield with less inputs makes soilless culture more attractive to the growers. In Turkey for example, when economic aspects of soilless and soil-based greenhouse cucumber production were analyzed, there was $25 \%$ higher net return from cucumber grown in perlite and zeolite mixture as compared to the conventional soil-based cultivation [137]. With good quality produce, improved phytosanitary management and ease of implementation, soilless culture can be highly productive method [138]. In spite of that, Pythium spp. and Phytophthora spp. are among the pathogenic organisms which are detected in soilless culture [139-141]. In the period of stress, because of high temperatures and low dissolved oxygen in the nutrient solution, Pythium and Phytophthora disease epidemics can occur more easily in soilless culture [142-144]. Regardless of the issues associated with soilless culture, we can always optimize the system following different methods. Passive methods like slow filtration, heat treatment, UV-treatment and use of disinfectant like sodium hypochloride $\left(\mathrm{NaOCl}_{2}\right)$ [145], addition of biocontrol agents like Pseudomonas, Burkholderia, Bacillus, Penicillium, Trichoderma species, and other non-pathogenic fungi/bacteria which can improve the biological interaction, thus reducing harmful plant pathogens [135]. As these methods are mostly tested in vitro, these results cannot be fully correlated in greenhouses. Therefore, further research in these methods for optimizing the performance of soilless growing system is needed.

\subsection{Chemical Control}

Chemical control is an effective method of controlling some soilborne diseases in agricultural crops. As non-chemical alternative methods can be time-consuming and less effective against soilborne plant pathogens, the growers are turning to many known chemical alternatives to methyl bromide for soil fumigation [146]. Chemical control of soilborne plant pathogens is generally preferred in large crop production areas due to relatively rapid effect and easy operation. Products in the dicarboximide, benzimidazole and triazole fungicide groups are known to control certain soilborne fungal disease effectively $[147,148]$. Bubici and his colleagues demonstrated the effective reduction of Verticillium wilt in eggplant using strobilurins under field and greenhouse conditions [149]. Similarly, azoxystrobine fungicides are often used to control $R$. solani $[2,150,151]$. Cyprodinil and fludioxonil-based fungicides are widely recommended to use against $S$. sclerotiorum [152,153]. However, it is important to recognize the impact of long-term fungicide and fumigants use such as influence on microbial growth and activity, reduced fertility and productivity and the emergence of fungicide resistance in pathogens [154]. Therefore, in an attempt to control the pathogens, we should also be aware of the downside of chemical fungicide use. Dekker reported the quick development of resistance to metalaxyl after its introduction [155]. Pathogen resistance to fungicides is becoming more common, and the performance of many fungicides has been affected to some degree by pathogens that develop resistance. Using different mode of action in rotation for a fungicide program is an important step toward reducing the risk of resistance development. Many environment-friendly chemicals and non-chemicals are being developed; again, their consistency and effectiveness are still found to be lower than methyl bromide [8]. Generally, minor diseases should be controlled using the management practices listed above, while the use of fungicides and fumigants should be reserved as the last step for soilborne disease control which adversely affects the aesthetics, marketability and health of the crops.

\subsection{Biological Control}

Chemical methods are easy, quick and effective; yet, they can cause a disturbance in the environment, adversely affect human health, damage aquatic ecosystems, harm pollinators and reduce populations of beneficial microorganisms in the soil. The application of biocontrol agents to the soil is an alternative to suppress soilborne plant pathogens through parasitism, production of antagonistic chemicals, competition for the host and nutrients, and induction of resistance in plants against disease-causing pathogens [83]. Several organisms are successfully used as biocontrol agents for controlling soilborne pathogens (Table 1). The bacterial and fungal genera that are commercially 
employed as biological control agents include Gliocladium, Bacillus, Coniothyrium, Paecilomyces, Phlebiopsis, Pseudomonas, Rhizobium, Serratia, Streptomyces, and Trichoderma [156]. The application of biocontrol agents in soil such as T. viride, T. harzianum, fluorescent Pseudomonas and B. subtilis have been found to be effective against root rot caused by soilborne plant pathogens in a number of crops $[83,157]$. Trichoderma species are known to produce large quantities of fungi-toxic metabolites. They are the active mycoparasites which have been used as effective biocontrol agents against foliar and soilborne disease, as well as plant parasitic soilborne nematodes [83,158]. Meyer and his colleagues have investigated the use of Trichoderma species against root-knot nematodes on a wide range of crops such as tomato, okra, mungbean, and bell pepper [159]. Dennis and Webster reported the antagonistic ability of T. harzianum against several soilborne diseases [160-162]. Use of mycoparasite, C. minitans, to effectively manage S. sclerotiorum is widely used. C. minitants produce cell-wall degrading enzymes such as chitinases and glucanases that can enhance the colonization and degradation of sclerotia produced by S. sclerotiorum $[163,164]$. A few studies also demonstrated the direct penetration, degradation and disintegration of sclerotia by C. minitants $[165,166]$. Similarly, Henis and Papavizas explained the phenomena of inhibition of sclerotial germination of $S$. rolfsii, by Trichoderma, as a competition for nutrients $[167,168]$. The antifungal substance obtained from the bacterium B. amyloliquefaciens was found to be effective to inhibit the mycelial growth of some pathogenic fungi such as Alternaria panax, Botrytis cinera, C. orbiculare, Penicillium digitatum, P. grisea and S. sclerotiorum [169]. Zhang and his colleagues also explained the inhibition of plant pathogenic fungi such as C. orbiculare, P. capsici, Corynespora cassicola and F. oxysporum with prenylated indole derivative from the endophytic bacteria Streptomyces species [170]. Not only the antagonistic bacteria and fungi, but also arbuscular mycorrhizal fungi have been used to control soilborne diseases [171]. Mycorrhizal fungi cover the plant root, forming a fungal mat, and protect plant roots by providing the physical barrier to the pathogen, providing antagonistic chemicals, increasing nutrient-uptake ability of plants, and a direct competition with the pathogen. The most common type of mycorrhizal association, vesicular arbuscular endo-mycorrhizas (VAMs), are formed by almost all cultivated plants which may be agronomical, horticultural or fruit crops [172]. VAMs can reduce the potential damage from Rhizoctonia on several plants, Verticillium wilt of cotton [173], Fusarium crown and root rot, and P. nicotianae on tomato [174]. Although the use of biological control methods for the effective management of soilborne diseases has been a long-term goal in sustainable agriculture, the efficacy of this method is highly dependent on the integrated approaches to maintaining soil health and controlling soilborne pathogens.

Table 1. Some important biological control agents with their mode of action and target soilborne pathogens.

\begin{tabular}{|c|c|c|c|}
\hline Biocontrol Agents & Target Pathogen & Mode of Action & Reference \\
\hline $\begin{array}{l}\text { Bacillus spp. (B. subtilis, } \\
\text { B. amyloliquefaciens, } \\
\text { B. firmus and B. pumilus) }\end{array}$ & $\begin{array}{l}\text { Pythium spp., Fusarium spp., } \\
\text { Rhizoctonia solani, } \\
\text { Aspergillus flavus }\end{array}$ & $\begin{array}{l}\text { Competition, direct } \\
\text { antibiosis, induced } \\
\text { resistance }\end{array}$ & {$[175,176]$} \\
\hline Coniothyrium minitans & $\begin{array}{l}\text { Sclerotinia sclerotiorum and } \\
\text { S. trifoliorum }\end{array}$ & $\begin{array}{l}\text { Lysis by chitinase } \\
\text { and } \beta-1,3 \text { glucanase }\end{array}$ & [175] \\
\hline Gliocladium catenulatum & $\begin{array}{l}\text { Species of Rhizoctonia, Pythium, } \\
\text { Phytophthora, Fusarium, } \\
\text { Didymella, Botrytis, Verticillium, } \\
\text { Alternaria, Cladosporium, } \\
\text { Helminthosporium, Penicillium } \\
\text { and Plicaria }\end{array}$ & Toxin production & [175] \\
\hline $\begin{array}{l}\text { Purpureocillium lilacinum } \\
\text { QLP } 12 \text { (previously } \\
\text { Paecilomyces lilacinus) }\end{array}$ & $\begin{array}{l}\text { Verticillium dahliae, R. solani } \\
\text { and nematodes }\end{array}$ & Parasitism & [177] \\
\hline
\end{tabular}


Table 1. Cont.

\begin{tabular}{|c|c|c|c|}
\hline Biocontrol Agents & Target Pathogen & Mode of Action & Reference \\
\hline Phlebiopsis gigantea & Heterobasidion annosum & $\begin{array}{l}\text { Competition for } \\
\text { resources }\end{array}$ & [175] \\
\hline Pseudomonas spp. & Pythium spp. R. solani & $\begin{array}{l}\text { Production of } \\
\text { antibiotics, } \\
\text { siderophores, } \\
\text { volatiles }\end{array}$ & {$[175,178]$} \\
\hline Pythium oligandrum & $\begin{array}{l}\text { Species of Alternaria, Botrytis, } \\
\text { Fusarium, Gaeumannonyces, } \\
\text { Ophistoma, Phoma, } \\
\text { Pseudocercosporella, Pythium, } \\
\text { Sclerotinia and Sclerotium }\end{array}$ & Hyperparasitism & [175] \\
\hline Streptomyces spp. & $\begin{array}{l}\text { Species of Fusarium, } \\
\text { Rhizoctonia, Phytophthora, } \\
\text { Pythium, Phytomatotricum, } \\
\text { Aphanomyces, Monosprascus, } \\
\text { Armillaria, Sclerotinia, } \\
\text { Verticillium, Geotrichum }\end{array}$ & Mycoparasitism & [175] \\
\hline $\begin{array}{l}\text { Trichoderma spp. } \\
\text { (T. atroviride, T. asperellum, } \\
\text { T. harzianum, T. viridae, } \\
\text { T. gamsii and T. polysporum) }\end{array}$ & $\begin{array}{l}\text { Species of Rhizoctonia, } \\
\text { Fusarium, Alternaria and } \\
\text { Colletotrichum as well as } \\
\text { oomycetes, such as Pythium } \\
\text { and Phytophthora }\end{array}$ & $\begin{array}{l}\text { Competition, } \\
\text { resistance and } \\
\text { hyperparasitism }\end{array}$ & [175] \\
\hline
\end{tabular}

\section{System-Based Approach for Soilborne Disease Management}

Generally, but not always, the application of corrective systems to manage soilborne diseases can be only for short term. The increasing trend of combining different methods illustrates the importance of integrated soilborne disease management as well as opens up the concerns regarding environmental health. Integrated soilborne disease management uses all the available tactics such as physical, cultural, legal, biological and chemical if urgent, for the effective and sustainable management of soilborne diseases. Limited availability of soilborne disease management strategies and their effectiveness under particular conditions leads to a redesign of the crop production system with more robust and sustainable solutions. A system-based approach emphasizes the incorporation of different practices into the design and operation of a cropping system which aids disease suppression through natural biological feedback mechanisms [179]. Chellemi and his colleagues illustrated the system-based approach with case studies related to Verticillium wilt and Fusarium wilt as an effective way to manage soilborne diseases. This approach consists of the following steps: (i) prevention of introduction and spread of pathogen; (ii) reduction of high pathogen level to the point where they can be managed effectively using natural systems; (iii) promotion of disease suppressive soil microbial communities; and (iv) use of an integrative approach to interfare with the life cycle of pathogens and minimizing the use of disruptive actions such as pesticides and biopesticides. For example, for the effective management of Verticillium wilt, the first step would be the use of clean seed and transplant [179]. When the pathogen level is high enough to cause significant economic losses, soil disinfestation using different fumigation methods can be adopted. For the long-term management, integration of crop rotation (strawberry-cover crop-broccoli-lettuce in this case), addition of organic amendments can be used to alter the microbial composition to suppress Verticillium wilt. In addition, crop termination treatments to mitigate inoculum build up and transfer is desirable. However, deep understanding of the multiple interactions at different trophic levels is advisable to design and implement a systems-based approach for disease management $[180,181]$. Colla and his colleagues reviewed the use of an integrated approach for the effective management of different pathogens as the phaseout of methyl-bromide leads to knowledge about the pathogens' biology, ecology and management [182]. Larkin reviewed 
the strategies for soil health management in which he suggested importance of maintaining and diversifying soil biota by integrated soil health management approaches [183]. Newton and his colleagues reviewed different type of host-microbe interaction that can be present in the soil such as positive, negative and positive or negative interaction depending upon the ecosystem, there is no single answer to the problems faced by growers [184]. Besides, a general recommendation for using a system-based approach based on current research would be the integrated use of different methods explained above. For example, soil solarization to manage different soilborne diseases as a pre-planting measure followed by use of clean seed materials to reduce the chance of introduction; use of Brassica cover crops as a natural source of biofumigants in coherence with crop rotation, to reduce the chance of pathogen build up due to monoculture; and introduction of biocontrol agents to the ecosystem.

\section{Conclusions}

Soilborne diseases are among the most destructive elements in crop production. Many vegetable crops, other high-value crops and ornamentals are vulnerable to the wide range of disease-causing organisms that either reduce the yield, aesthetics, marketability or many aspects combined. The phase-out of many chemicals and rising awareness towards resistance development, environmental health, and climate change necessitates the quest for alternative suitable management options. Many non-chemical options such as sanitation, legal methods, resistant cultivars/varieties and grafting, cropping system, soil solarization, biofumigants, soil amendments, anaerobic soil disinfestation, soil steam sterilization, soil fertility and plant nutrients, soilless culture and biological control methods may prove costly and inefficient when used alone. However, soilborne plant pathogens can be managed below the economic threshold level when these methods are applied as a system approach. Although the integrated soilborne disease management strategies may not eradicate all the pathogenic organisms from the soil, it entails continuous exploration and research for sustainable crop production which will secure a sustainable future for an ever-growing population.

Author Contributions: M.P. and F.B.-G. wrote the paper; F.B.-G., M.P. and S.C.H. revised the paper; F.B.-G received the funding. All authors have read and agreed to the published version of the manuscript.

Funding: This work was supported by the National Institute of Food and Agriculture (NIFA), United States Department of Agriculture (USDA) Evans-Allen grant, under award numbers TENX-1926-CCOCP and TENX-S-1083, and the NIFA, USDA, Southern Sustainable Agriculture Research and Education program under award number OS18-112.

Conflicts of Interest: The authors declare no conflict of interest.

\section{References}

1. Lewis, J.A.; Papavizas, G.C. Biocontrol of cotton damping-off caused by Rhizoctonia solani in the field with formulations of Trichoderma spp. and Gliocladium virens. Crop Prot. 1991, 10, 396-402. [CrossRef]

2. Mihajlović, M.; Rekanović, E.; Hrustić, J.; Tanović, B. Methods for management of soilborne plant pathogens. Pestic. Fitomedicina 2017, 32, 9-24. [CrossRef]

3. Baysal-Gurel, F.; Kabir, N. Comparative performance of fungicides and biocontrol products in suppression of Rhizoctonia root rot in viburnum. J. Plant Pathol. Microbiol. 2018, 9, 451. [CrossRef]

4. Mokhtar, M.M.; El-Mougy, N.S. Biocompost application for controlling soilborne plant pathogens-A review. Int. J. Eng. Innov. Technol. 2014, 4, 61-68.

5. Åström, B.; Gerhardson, B. Differential reactions of wheat and pea genotypes to root inoculation with growth-affecting rhizosphere bacteria. Plant Soil 1988, 109, 263-269. [CrossRef]

6. Bell, C.H. Alternative physical methods and emission reduction. In The Methyl Bromide Issue; Bell, C.H., Price, N., Chakrabarti, B., Eds.; John Wiley and Sons: West Sussex, UK, 1996; pp. 323-329.

7. Keinath, A.P.; Batson, W.E. Evaluation of biological and chemical seed treatments to improve stand of snap bean across the southern U.S. Crop Prot. 2000, 19, 501-509. [CrossRef]

8. Gerik, J.S.; Hanson, B.D. Drip application of methyl bromide alternative chemicals for control of soilborne pathogens and weeds. Pest Manag. Sci. 2011, 67, 1129-1133. [CrossRef] 
9. Christopher, D.J.; Raj, T.S.; Rani, S.U.; Udhayakumar, R. Role of defense enzymes activity in tomato as induced by Trichoderma virens against Fusarium wilt caused by Fusarium oxysporum f.sp. lycopersici. J. Biopestic. 2010, 3, 158-162.

10. Bolwerk, A.; Lagopodi, A.L.; Lugtenberg, B.J.; Bloemberg, G.V. Visualization of interactions between a pathogenic and a beneficial Fusarium strain during biocontrol of tomato foot and root rot. Mol. Plant Microbe Interact. 2005, 18, 710-721. [CrossRef]

11. Benítez, M.S.; Baysal, F.; Rotenberg, D.; Kleinhenz, M.D.; Cardina, J.; Stinner, D.; Miller, S.A.; McSpadden Gardener, B. Linking changes in bacterial populations with disease suppression, as affected by agricultural management strategies. Soil Biol. Biochem. 2007, 39, 2289-2301. [CrossRef]

12. Borneman, J.; Becker, J.O. Identifying microorganisms involved in specific pathogen suppression in soil. Phytopathology 2007, 45, 153-172.

13. Gross, H.; Stockwell, V.O.; Henkels, M.D.; Nowak-Thompson, B.; Loper, J.E.; Gerwick, W.H. The genomisotopic approach: A systematic method to isolate products of orphan biosynthetic gene clusters. Chem. Biol. 2007, 14, 53-63. [CrossRef]

14. Baysal-Gurel, F.; Kabir, N.; Liyanapathiranage, P. Effect of organic inputs and solarization for the suppression of Rhizoctonia solani in woody ornamental plant production. Plants 2019, 8, 138. [CrossRef] [PubMed]

15. Baysal-Gurel, F.; Liyanapathiranage, P.; Addesso, K. Effect of Brassica crop-based biofumigation on soilborne disease suppression in woody ornamentals. Can. J. Plant Pathol. 2019. [CrossRef]

16. Hoitink, H.A.J.; Boehm, M.J. Biocontrol within the context of soil microbial communities: A substrate-dependent phenomenon. Annu. Rev. Phytopathol. 1999, 37, 427-446. [CrossRef] [PubMed]

17. Han, D.Y.; Coplin, D.L.; Bauer, W.D.; Hoitink, H.A.J. A rapid bioassay for screening rhizosphere microorganisms for their ability to induce systemic resistance. Phytopathology 2000, 90, 327-332. [CrossRef] [PubMed]

18. Krause, M.S.; De Ceuster, T.J.J.; Tiquia, S.M.; Michel, F.C.; Madden, L.V.; Hoitink, H.A.J. Isolation and characterization of rhizobacteria from composts that suppress the severity of bacterial leaf spot of radish. Phytopathology 2003, 93, 1292-1300. [CrossRef]

19. Alfano, G.; Lewis Ivey, M.L.; Cakir, C.; Bos, J.I.B.; Miller, S.A.; Madden, L.V.; Kamoun, S.; Hoitink, H.A.J. Systemic modulation of gene expression in tomato by Trichoderma hamatum 382. Phytopathology 2007, 97, 429-437. [CrossRef]

20. Mazzola, M. Assessment and management of soil microbial community structure for disease suppression. Annu. Rev. Phytopathol. 2004, 42, 35-59. [CrossRef]

21. Claude, A.; Clarkson, J.; de Cara, F.M.; de Caravalho Franca, S.; Debode, J.; Elorrieta, M.; Furlan, L.; Grand, A.; Hinarejos Esteve, E.; Kos, J.; et al. EIP-AGRI Focus Group on Soil-Borne Diseases: Final Report; EIP-AGRI Focus Group, IPM practices for soil-borne diseases, European Commission, Brussels, Belgium: 2015. Available online: https://ec.europa.eu/eip/agriculture/sites/agri-eip/files/eip-agri_focus_group_on_ ipm_practices_for_soil-borne_diseases_final_report_2015.pdf (accessed on 6 December 2019).

22. Baysal-Gurel, F.; Gardener, B.M.; Miller, S.A. Soilborne Disease Management in Organic Vegetable Production. 2012. Available online: https://eorganic.org/node/7581 (accessed on 7 December 2019).

23. Crooks, J.A. Lag times and exotic species: The ecology and management of biological invasions in slow-motion. Ecoscience 2005, 12, 316-329. [CrossRef]

24. Goss, E.M.; Carbone, I.; Grunwald, N.J. Ancient isolation and independent evolution of the three clonal lineages of the exotic sudden oak death pathogen Phytophthora ramorum. Mol. Ecol. 2009, 18, 1161-1174. [CrossRef] [PubMed]

25. Moralejo, E.; Perez-Sierra, A.M.; Alvarez, L.A.; Belbahri, L.; Lefort, F.; Descals, E. Multiple alien Phytophthora taxa discovered on diseased ornamental plants in Spain. Plant Pathol. 2009, 58, 100-110. [CrossRef]

26. Sikes, B.A.; Bufford, J.L.; Hulme, P.E.; Cooper, J.A.; Johnston, P.R.; Duncan, R.P. Import volumes and biosecurity interventions shape the arrival rate of fungal pathogens. PLoS Biol. 2018, 16, 100-101. [CrossRef] [PubMed]

27. De Benedictis, L.; Tajoli, L. The world trade network. World Econ. 2011, 34, 1417-1454. [CrossRef]

28. The World Bank, International Civil Aviation Organization. Civil Aviation Statistics of the World and ICAO Staff Estimates: Air Transport, Passengers Carried [Internet]; The World Bank: Washington, DC, USA, 2016; Available online: https://data.worldbank.org/indicator/IS.AIR.PSGR (accessed on 15 October 2019). 
29. Hulme, P.E. Trade, transport and trouble: Managing invasive species pathways in an era of globalization. J. Appl. Ecol. 2009, 46, 10-18. [CrossRef]

30. Lambin, E.F.; Meyfroidt, P. Global land use change, economic globalization, and the looming land scarcity. Proc. Natl. Acad. Sci. USA 2011, 108, 3465-3472. [CrossRef]

31. Fisher, M.C.; Henk, D.A.; Briggs, C.J.; Brownstein, J.S.; Madoff, L.C.; McCraw, S.L.; Gurr, S.J. Emerging fungal threats to animal, plant and ecosystem health. Nature 2012, 484, 186-194. [CrossRef]

32. Tittensor, D.P.; Walpole, M.; Hill, S.L.; Boyce, D.G.; Britten, G.L.; Burgess, N.D.; Butchart, S.H.M.; Leadley, P.W.; Regan, E.C.; Alkemade, R.; et al. A mid-term analysis of progress toward international biodiversity targets. Science 2014, 346, 241-244. [CrossRef]

33. Seebens, H.; Blackburn, T.M.; Dyer, E.E.; Genovesi, P.; Hulme, P.E.; Jeschke, J.M.; Pagad, S.; Pyšek, P.; Winter, M.; Arianoutsou, M.; et al. No saturation in the accumulation of alien species worldwide. Nat. Commun. 2017, 8, 14435. [CrossRef]

34. Katan, J. Diseases caused by soilborne pathogens: Biology, management and challenges. J. Plant Pathol. 2017, 99, 305-315.

35. Davis, J.R.; Pavek, J.J.; Corsini, D.L.; Sorensen, L.H. Stability of Verticillium resistance of potato clones and changes in soilborne populations with potato monoculture. In Proceedings of the Soil-Borne Diseases of 4th International Congress of Plant Pathology, Melbourne, Australia, 17-24 August 1985; pp. 165-166.

36. Christou, P. Plant genetic engineering and agricultural biotechnology 1983-2013. Trends Biotechnol. 2013, 31, 125-127. [CrossRef] [PubMed]

37. Karlovsky, P. Biological detoxification of the mycotoxin deoxynivalenol and its use in genetically engineered crops and feed additives. Appl. Microbiol. Biotechnol. 2011, 91, 491-504. [CrossRef] [PubMed]

38. Dong, O.X.; Ronald, P.C. Genetic engineering for disease resistance in plants: Recent progress and future perspectives. Plant Physiol. 2019, 180, 26-38. [CrossRef] [PubMed]

39. Juge, N. Plant protein inhibitors of cell wall degrading enzymes. Trends Plant Sci. 2006, 11, 359-367. [CrossRef] [PubMed]

40. Bruton, B. Grafting watermelon onto squash or gourd rootstock makes firmer, healthier fruit. Agric. Res. 2005, 53, 8-9.

41. Rivard, C.; Louws, F. Grafting for disease resistance in heirloom tomatoes. North Carolina, USA, North Carolina Cooperative Extension Service, North Carolina State University. 2006. Available online: http: //www4.ncsu.edu/ \{\}clrivard/TubeGraftingTechnique.pdf (accessed on 6 December 2019).

42. Lee, J.M.; Oda, M. Grafting of herbaceous vegetable and ornamental crops. Hortic. Rev. 2003, 28, 61-124.

43. Cohen, R.; Burger, Y.; Horev, C.; Koren, A.; Edelstein, M. Introducing grafted cucurbits to modern agriculture. Plant Dis. 2007, 91, 916-923. [CrossRef]

44. Rabinowitch, H.D.; Cohen, R. Genetics and breeding for resistance and grafting for protection against Fusarium oxysporum wilts. In Fusarium Wilts of Greenhouse Vegetable and Ornamental Crops; Gullino, M.L., Katan, J., Garibaldi, A., Eds.; APS Press: St. Paul, MN, USA, 2012; pp. 83-100.

45. Rouphael, Y.; Kyriacou, M.C.; Colla, G. Vegetable grafting: A toolbox for securing yield stability under multiple stress conditions. Front. Plant Sci. 2018, 8, 2255. [CrossRef]

46. Stitger, H.C.M. Some aspects of the physiological functioning of the graft muskmelon/Cucurbita ficifolia. Publ./Cent. Plant Physiol. Res. 1971, 65, 223-231.

47. Harnett, R.F. Resurgence of interest in grafting techniques on heated tomato crops. Grower 1974, 82, 861-862.

48. Edelstein, M. Grafting vegetable-crop plants: Pros and Cons. Acta Hort. 2004, 659, 235-238. [CrossRef]

49. Umaerus, V.R.; Scholte, K.; Turkensteen, L.J. Crop rotation and the occurrence of fungal diseases in potatoes. In Effects of Crop Rotation on Potato Production in the Temperate Zones; Vos, J., Loon, C.D., van Bollen, G.J., Eds.; Springer: Dordrecht, The Netherlands, 1989; pp. 171-189. [CrossRef]

50. Sullivan, P. Sustainable Management of Soil-Borne Plant Diseases; ATTRA, USDA's Rural Business Cooperative Service: Washington, DC, USA, 2001; Available online: www.attra.org (accessed on 7 December 2019).

51. Johnston, H.W.; Celetti, M.J.; Kimpinski, J.; Platt, H.W. Fungal pathogens and Pratylenchus penetrans associated with preceding crops of clovers, winter wheat, and annual ryegrass and their influence on succeeding potato crops on Prince Edward Island. Am. J. Potato Res. 1994, 71, 797-808. [CrossRef]

52. Larkin, R.P.; Griffin, T.S.; Honeycutt, C.W. Rotation and cover crop effects on soilborne potato diseases, tuber yield, and soil microbial communities. Plant Dis. 2010, 94, 1491-1502. [CrossRef] [PubMed]

53. Kheyrodin, H. Crop rotations for managing soil-borne plant diseases. Afr. J. Food Sci. Technol. 2010, 1, 1-9. 
54. Carling, D.E.; Baird, R.E.; Gitaitis, R.D.; Brainard, K.A.; Kuninaga, S. Characterization of AG-13, a newly reported anastomosis group of Rhizoctonia solani. Phytopathology 2002, 92, 893-899. [CrossRef]

55. Kobayashi-Leonel, R.; Mueller, D.; Harbach, C.; Tylka, G.; Leandro, L. Susceptibility of cover crop plants to Fusarium virguliforme, causal agent of soybean sudden death syndrome, and Heterodera glycines, the soybean cyst nematode. J. Soil Water Conserv. 2017, 72, 575-583. [CrossRef]

56. Hiddink, G.A.; Termorshuizen, A.J.; Raaijmakers, J.M.; van Bruggen, A.H.C. Effect of mixed and single crops on disease suppressiveness of soils. Phytopathology 2005, 95, 1325-1332. [CrossRef]

57. Katan, J.; Greenberger, A.; Alon, H.; Grinstein, A. Solar heating by polyethylene mulching for the control of diseases caused by soil-borne pathogens. Phytopathology 1976, 66, 683-688. [CrossRef]

58. Elad, Y.; Katan, J.; Chet, I. Physical, biological, and chemical control integrated for soilborne diseases in potatoes. Phytopathology 1980, 70, 418-422. [CrossRef]

59. Gutkowski, D.; Terranova, S. Physical aspects of soil solarization. In Soil Solarization, Proceedings of the First Conference on Soil Solarization, Amman, Jordan; DeVay, J.E., Stapleton, J.J., Elmore, C.L., Eds.; FAO plant production and protection paper: Rome, Italy, 19-25 February 1991; Volume 109, pp. 48-61.

60. Al-Kayssi, A.W.; Al-Karaghouli, A. A new approach for soil solarization by using paraffin-wax emulsion as a mulching material. Renew. Energy 2002, 26, 637-648. [CrossRef]

61. Zheng, Y.; Yanful, E.K.; Bassi, A.S. A review of plastic waste biodegradation. Critical Reviews in Biotechnology 2005, 25, 243-250. [CrossRef] [PubMed]

62. Nakamura, K.; Watanabe, S.; Ozaki, H.; Ikeura, Y.; Kotani, A. Soil temperature and moisture environments: Lot-management water requirements associated with soil solarization. Farml. Agric. 2011, 631, 2-10.

63. Dai, Y.Y.; Kondo, M.; Ito, K.; Yoshiyama, K.; Zhang, P.F.; Zhang, F.P.; Senge, M. Study on irrigation water requirements for the control of Ralstonia solanacearum via soil solarization in managing tomato cultivation. J. Irrig. Drain. Rural Eng. 2014, 294, 85-92.

64. Larkin, R.P.; Honeycutt, C.W. Effects of different 3-year cropping systems on soil microbial communities and Rhizoctonia diseases of potato. Phytopathology 2006, 96, 68-79. [CrossRef] [PubMed]

65. Larkin, R.P.; Griffin, T.S. Control of soilborne diseases of potato using Brassica green manures. Crop Prot. 2007, 26, 1067-1077. [CrossRef]

66. Baysal-Gurel, F.; Liyanapathiranage, P.; Mullican, J. Biofumigation: Opportunities and challenges for control of soilborne diseases in nursery production. Plant Health Prog. 2018, 332-337. [CrossRef]

67. Auger, J.; Arnault, I.; Diwo-Allain, S.; Ravier, F.; Molia, M.; Pettiti, M. Insecticidal and fungicidal potential of Allium products and substances as biofumigants. Agroindustria 2004, 3, 367-370.

68. Arnault, I.; Fleurance, C.; Vey, F.; Du Fretay, G.; Auger, J. Use of Alliaceae residues to control soil-borne pathogens. Ind. Crop. Prod. 2013, 49, 265-272. [CrossRef]

69. Hao, J.; Subbarao, K.V. Effects of broccoli rotations on lettuce drop caused by Sclerotinia minor and on the population density of sclerotia in soil. Plant Dis. 2003, 87, 159-166. [CrossRef]

70. Ramirez-Villapudua, J.; Munnecke, D.E. Control of cabbage yellow (Fusarium oxysporum f.sp. conglutinans) by solar heating of field soils amended with dry cabbage residues. Plant Dis. 1987, 71, 217-221. [CrossRef]

71. Lewis, J.A.; Papavizas, G.C. Evolution of volatile sulfur-containing compounds from decomposition of crucifers in soil. Soil Biol. Biochem. 1970, 2, 239-246. [CrossRef]

72. Lewis, J.A.; Papavizas, G.C. Effect of sulfur-containing volatile compounds and vapours from cabbage decomposition on Aphanomyces Euteiches. Phytopathology 1971, 61, 208-214. [CrossRef]

73. Lewis, J.A.; Papavizas, G.C. Effect of volatiles from decomposing plant tissues on pigmentation, growth, and survival of Rhizoctonia Solani. Soil Sci. 1974, 118, 156-163. [CrossRef]

74. Matthiessen, J.N.; Shackleton, M.A. Biofumigation: Environmental impacts on the biological activity of diverse pure and plant-derived isothiocyanates. Pest Manag. Sci. 2005, 61, 1043-1051. [CrossRef]

75. Brown, P.D.; Morra, M.J. Control of soilborne plant pests using glucosinolate containing plants. Adv. Agron. 1997, 61, 167-231.

76. Kwerepe, B.C.; Labuschagne, N. Biofumigation and solarization as integrated pest management (IPM) components for the control of root knot nematode (Meloidogyne incognita (Kofoid \& White) Chitwoodi) on bambara groundnut (Vigna subterranea (L.) verdc.). UNISWA J. Agric. 2003, 11, 56-63. 
77. Clarkson, J.; Michel, V.; Neilson, R. Focus group in soilborne diseases: Biofumigation for the control of soil-borne diseases. In EIP-AGRI Focus Group on Soil-Borne Diseases: Final Report; Claude, A., Clarkson, J., de Cara, F.M., de Caravalho Franca, S., Debode, J., Elorrieta, M., Furlan, L., Grand, A., Hinarejos Esteve, E., Kos, J., et al., Eds.; EIP-AGRI: Brussels, Belgium, 2015; pp. 1-7.

78. Omirou, M.; Rousidou, C.; Bekris, F.; Papadopoulou, K.K.; Menkissoglou-Spiroudi, U.; Ehaliotis, C. The impact of biofumigation and chemical fumigation methods on the structure and function of the soil microbial community. Microb. Ecol. 2011, 61, 201-213. [CrossRef]

79. Paret, M.L.; Cabos, R.; Kratky, B.A.; Alvarez, A.M. Effect of plant essential oils on Ralstonia solanacearum race 4 and bacterial wilt of edible ginger. Plant Dis. 2010, 94, 521-527. [CrossRef]

80. Kirkegaard, J.A.; Sarwar, M.; Wong, P.T.W.; Mead, A.; Howe, G.; Newell, M. Field studies on the biofumigation of take-all by Brassica break crops. Aust. J. Agric. Res. 2000, 51, 445-456. [CrossRef]

81. El-Sharouny, E.E. Effect of different soil amendments on the microbial count correlated with resistance of apple plants towards pathogenic Rhizoctonia solani AG-5. Biotechnol. Biotechnol. Equip. 2015, 29, 463-469. [CrossRef]

82. Bonanomi, G.; Antignani, V.; Pane, C.; Scala, F. Suppression of soilborne fungal diseases with organic amendments. J. Plant Pathol. 2007, 89, 311-324.

83. Shafique, H.A.; Sultana, V.; Ehteshamul-Haque, S.; Athar, M. Management of soil-borne diseases of organic vegetables. J. Plant Prot. Res. 2016, 56, 221-230. [CrossRef]

84. Welke, S.E. The effect of compost extract on the yield of strawberries and the severity of Botrytis cinerea. J. Sustain. Agric. 2005, 25, 57-68. [CrossRef]

85. Bonanomi, G.; Lorito, M.; Vinale, F.; Woo, S.L. Organic amendments, beneficial microbes, and soil microbiota: Toward a unified framework for disease suppression. Annu. Rev. Phytopathol. 2018, 56, 1-20. [CrossRef] [PubMed]

86. Allard, S.M.; Walsh, C.S.; Wallis, A.E.; Ottesen, A.R.; Brown, E.W.; Micallef, S.A. Solanum lycopersicum (tomato) hosts robust phyllosphere and rhizosphere bacterial communities when grown in soil amended with various organic and synthetic fertilizers. Sci. Total Environ. 2016, 573, 555-563. [CrossRef]

87. Inderbitzin, P.; Ward, J.; Barbella, A.; Solares, N.; Izyumin, D.; Burman, P.; Chellemi, D.O.; Subbarao, K.V. Soil microbiomes associated with Verticillium wilt suppressive broccoli and chitin amendments are enriched with potential biocontrol agents. Phytopathology 2018, 108, 31-43. [CrossRef]

88. Ling, N.; Zhu, C.; Xue, C.; Chen, H.; Duan, Y.; Peng, C.; Guo, S.; Shen, Q. Insight into how organic amendments can shape the soil microbiome in long-term field experiments as revealed by network analysis. Soil Biol. Biochem. 2016, 99, 137-149. [CrossRef]

89. Bonanomi, G.; Gaglione, S.A.; Cesarano, G.; Sarker, T.C.; Pascale, M.; Scala, F.; Zoina, A. Frequent applications of organic matter to agricultural soil increase fungistasis. Pedosphere 2017, 27, 86-95. [CrossRef]

90. Silber, A.; Levkovitch, I.; Graber, E.R. pH-dependent mineral release and surface properties of cornstraw biochar: Agronomic implications. Environ. Sci. Technol. 2010, 44, 9318-9323. [CrossRef]

91. Glaser, B.; Lehmann, J.; Zech, W. Ameliorating physical and chemical properties of highly weathered soils in the tropics with charcoal-a review. Biol. Fertil. Soils 2002, 35, 219-230. [CrossRef]

92. Thies, J.E.; Rillig, M.C.; Graber, E.R. Biochar effects on the abundance, activity and diversity of the soil biota. In Biochar for Environmental Management: Science and Technology, 2nd ed.; Lehmann, J., Joseph, S., Eds.; Earthscan Books Ltd.: London, UK, 2015; pp. 327-389.

93. Brtnicky, M.; Dokulilova, T.; Holatko, J.; Pecina, V.; Kintl, A.; Latal, O.; Vyhnanek, T.; Prichystalova, J.; Datta, R. Long-term effects of biochar-based organic amendments on soil microbial parameters. Agronomy 2019, 9, 747. [CrossRef]

94. Jaiswal, A.K.; Graber, E.R.; Elad, Y.; Frenkel, O. Biochar as a management tool for soilborne diseases affecting early stage nursery seedling production. Crop Prot. 2019, 120, 34-42. [CrossRef]

95. Sullivan, D.M.; Miller, R.O. Compost quality attributes, measurements, and variability. In Compost Utilization in Horticultural Cropping Systems; Stofella, P.J., Kahn, B.A., Eds.; Lewis Publishers: Boca Raton, FL, USA, 2001; pp. 95-120.

96. Scheuerell, S.J.; Sullivan, D.M.; Mahaffee, W.F. Suppression of seedling damping-off caused by Pythium ultimum, P. irregulare and Rhizoctonia solani in container media amended with a diverse range of Pacific Northwest compost sources. Phytopathology 2005, 95, 306-315. [CrossRef] 
97. Debode, J.; Elorrieta, M.A.; Grand, A.; Pugliese, M. Focus group in soil borne diseases: Organic Matter, Compost. In EIP-AGRI Focus Group on Soil-Borne Diseases: Final Report; Claude, A., Clarkson, J., de Cara, F.M., de Caravalho Franca, S., Debode, J., Elorrieta, M., Furlan, L., Grand, A., Hinarejos Esteve, E., Kos, J., et al., Eds.; EIP-AGRI: Brussels, Belgium, 2015; pp. 1-7.

98. Kebrom, T.H.; Woldesenbet, S.; Bayabil, H.K.; Garcia, M.; Gao, M.; Ampim, P.; Awal, R.; Fares, A. Evaluation of phytotoxicity of three organic amendments to collard greens using the seed germination bioassay. Environ. Sci. Pollut. Res. 2019, 26, 5454-5462. [CrossRef]

99. Jaiswal, A.K.; Frenkel, O.; Elad, Y.; Lew, B.; Graber, E.R. Non-monotonic influence of biochar dose on bean seedling growth and susceptibility to Rhizoctonia solani: The "Shifted Rmax-Effect". Plant Soil 2015, 395, 125-140. [CrossRef]

100. Frenkel, O.; Jaiswal, A.K.; Elad, Y.; Lew, B.; Kammann, C.; Graber, E.R. The effect of biochar on plant diseases: What should we learn while designing biochar substrates? J. Environ. Eng. Landsc. Manag. 2017, 25, 105-113. [CrossRef]

101. Termorshuizen, A.J.; van Rijn, E.; van der Gaag, D.; Alabouvette, C.; Chen, Y.; Lagerlöf, J.; Malandrakis, A.A.; Paplomatas, E.J.; Rämert, B.; Ryckeboer, J.; et al. Suppressiveness of 18 composts against 7 pathosystems: Variability in pathogen response. Soil Biol. Biochem. 2006, 38, 2461-2477. [CrossRef]

102. De Clercq, D.; Vandesteen, L.; Coosemans, J.; Ryckeboer, J. Use of compost as suppressor of plant diseases. In Resource Recovery and Reuse in Organic Solid Waste Management; Lens, P., Hamelers, B., Hoitink, H., Bidlingmaier, W., Eds.; IWA Publishing: London, UK, 2004; pp. 317-337.

103. Okon-Levy, N.; Meller, Y.; Haile, Z.M.; Elad, Y.; Rav-David, E.; Jurkevitch, E.; Katan, J. Induced resistance to foliar diseases by soil solarization and Trichoderma harzianum. Plant Pathol. 2015, 64, 365-374. [CrossRef]

104. Blok, W.J.; Lamers, J.G.; Termorshuizen, A.J.; Bollen, A.J. Control of soilborne plant pathogens by incorporating fresh organic amendments followed by tarping. Phytopathology 2000, 30, 253-259. [CrossRef]

105. De Cara, M. Focus group in soilborne diseases: Anaerobic Soil Disinfestation and other techniques of 'non chemical' soil disinfestation technique. In EIP-AGRI Focus Group on Soil-Borne Diseases: Final Report; Claude, A., Clarkson, J., de Cara, F.M., de Caravalho Franca, S., Debode, J., Elorrieta, M., Furlan, L., Grand, A., Hinarejos Esteve, E., Kos, J., et al., Eds.; EIP-AGRI: Brussels, Belgium, 2015; pp. 3-5. [CrossRef]

106. Momma, N.; Kobara, Y.; Uematsu, S.; Kita, S.; Shinmura, A. Development of biological soil disinfestations in Japan. Appl. Microbiol. Biotechnol. 2013, 97, 3801-3809.

107. Shrestha, U.; Wszelaki, A.L.; Butler, D.M. Introduction to Anaerobic Soil Disinfestation as a Fumigant Alternative. 2014. Available online: https://extension.tennessee.edu/publications/Documents/SP765-A.pdf (accessed on 7 December 2019).

108. Strauss, S.L.; Greenhut, R.F.; McClean, A.E.; Kluepfel, D.A. Effect of anaerobic soil disinfestation on the bacterial community and key soilborne phytopathogenic agents under walnut tree-crop nursery conditions. Plant Soil 2017, 415, 493-506. [CrossRef]

109. Poret-Peterson, A.T.; Albu, S.; McClean, A.E.; Kluepfel, D.A. Shifts in soil bacterial communities as a function of carbon source used during anaerobic soil disinfestation. Front. Environ. Sci. 2019, 6, 160. [CrossRef]

110. Muramoto, J.; Shennan, C.; Baird, G.; Zavatta, M.; Koike, S.T.; Bolda, M.P.; Daugovish, O.; Dara, S.K.; Klonsky, K.; Mazzola, M.; et al. Optimizing anaerobic soil disinfestation for california strawberries. Acta Hortic. 2014, 1044, 215-220. [CrossRef]

111. Shennan, C.; Muramoto, J.; Lamers, J.; Mazzola, M.; Rosskopf, E.N.; Kokalis-Burelle, N.; Momma, N.; Butler, D.M.; Kobara, Y.; Pugliese, M. Anaerobic soil disinfestation for soilborne disease control in strawberry and vegetable systems: Current knowledge and future directions. Acta Hortic. 2014, 1044, 165-175. [CrossRef]

112. Shrestha, U.; Augé, R.M.; Butler, D.M. A meta-analysis of the impact of anaerobic soil disinfestation on pest suppression and yield of horticultural crops. Front. Plant Sci. 2016, 7, 1-20. [CrossRef]

113. Baker, K.F.; Olsen, C.M. Aerated steam for soil treatment. Phytopathology 1960, 50, 82.

114. Tanaka, S.; Kobayashi, T.; Iwasaki, K.; Yamane, S.; Maeda, K.; Sakurai, K. Properties and metabolic diversity of microbial communities in soils treated with steam sterilization compared with methyl bromide and chloropicrin fumigations. Soil Sci. Plant Nutr. 2003, 49, 603-610. [CrossRef]

115. Afek, U.; Orenstein, J. Disinfecting potato tubers using steam treatments. Can. J. Plant Pathol. 2002, $24,36-39$. [CrossRef]

116. Fennimore, S.A.; Martin, F.N.; Miller, T.C.; Broome, J.C.; Dorn, N.; Greene, I. Evaluation of a mobile steam applicator for soil disinfestation in California strawberry. HortScience 2014, 49, 1542-1549. [CrossRef] 
117. Kokalis-Burelle, N.; Rosskopf, E.N.; Butler, D.M.; Fennimore, S.A.; Holzinger, J. Evaluation of steam and soil solarization for Meloidogyne arenaria control in Florida floriculture crops. J. Nematol. 2016, 48, 183-192. [CrossRef]

118. Gutierrez, W.A.; Shew, H.D.; Melton, T.A. Sources of inoculum and management for Rhizoctonia solani damping-off on tobacco transplants under greenhouse conditions. Plant Dis. 1997, 81, 604-606. [CrossRef] [PubMed]

119. Minuto, G.; Gilardi, G.; Kejji, S.; Gullino, M.L.; Garibaldi, A. Effect of physical nature of soil and humidity on stream disinfestation. Acta Hortic. 2005, 698, 257-262. [CrossRef]

120. Luvisi, A.; Panattoni, A.; Materazzi, A. Heat treatments for sustainable control of soil viruses. Agron. Sustain. Dev. 2015, 35, 657-666. [CrossRef]

121. Samtani, J.B.; Gilbert, C.; Weber, J.B.; Subbarao, K.V.; Goodhue, R.E.; Fennimore, S.A. Effect of steam and solarization treatments on pest control, strawberry yield, and economic returns relative to methyl bromide fumigation. HortScience 2012, 47, 64-70. [CrossRef]

122. Samtani, J.B.; Ajwa, H.A.; Weber, J.B.; Browne, G.T.; Klose, S.; Hunzie, J.; Fennimore, S.A. Evaluation of non-fumigant alternatives to methyl bromide for weed control and crop yield in California strawberries (Fragaria ananassa L.). Crop Prot. 2011, 30, 45-51. [CrossRef]

123. Huber, D.M.; Graham, R.D. The role of nutrition in crop resistance and tolerance to diseases. In Mineral Nutrition of Crops: Fundamental Mechanisms and Implications; Rengel, Z., Ed.; Food Products Press: New York, NY, USA, 1999; pp. 169-206.

124. Huber, D.M.; Watson, R.D. Nitrogen form and plant disease. Annu. Rev. Phytopathol. 1974, 12, $139-165$. [CrossRef] [PubMed]

125. Huber, D.M.; Haneklaus, S. Managing nutrition to control plant disease. Landbauforsch Volkenrode 2007, 57, 313-322.

126. Myers, D.F.; Campbell, R.N. Lime and the control of clubroot of crucifers: Effects of $\mathrm{pH}$, calcium, magnesium, and their interactions. Phytopathology 1985, 75, 670-673. [CrossRef]

127. Jones, J.P.; Engelhard, A.W.; Woltz, S.S. Management of Fusarium wilt of vegetables and ornamentals by macro- and micro-element nutrition. p. 18-32. In Soilborne Plant Pathogens: Management of Diseases with Macro- and Micro-Elements; Engelhard, A.W., Ed.; American Phytopathological Society: St. Paul, MN, USA, $1989 ;$ p. 217.

128. Woltz, S.S.; Jones, J.P. Tomato Fusarium wilt control by adjustments in soil fertility. Proc. Fla. State Hortic. Soc. 1973, 86, 157-159.

129. Woltz, S.S.; Ebgelhard, A.W. Fusarium wilt of chrysanthemum: Effect of nitrogen source and lime on disease development. Phytopathology 1973, 63, 155-157. [CrossRef]

130. Foster, R.E.; Walker, J.C. Predisposition of tomato to Fusarium wilt. J. Agric. Res. 1947, 74, 165-185.

131. Dick, J.B.; Tisdale, H.B. Fertilizers in relation to incidence of wilt as affecting a resistant and susceptible variety. Phytopathology 1938, 28, 666-667.

132. Dordas, C. Role of nutrients in controlling plant diseases in sustainable agriculture. A review. Agron. Sustain. Dev. 2008, 28, 33-46. [CrossRef]

133. Hooley, P.; Shaw, D.S. Inheritance of sensitivity to heavy metals in Phytophthora drechsleri. Trans. Br. Mycol. Soc. 1985, 85, 677-682. [CrossRef]

134. Graham, D.R.; Webb, M.J. Micronutrients and disease resistance and tolerance in plants. In Micronutrients in Agriculture, 2nd ed.; Mortvedt, J.J., Cox, F.R., Shuman, L.M., Welch, R.M., Eds.; Soil Science Society of America, Inc.: Madison, Wisconsin, WI, USA, 1991; pp. 329-370.

135. Vallance, J.; Deniel, F.; Le Floch, G.; Guerin-Dubrana, L.; Blancard, D.; Rey, P. Pathogenic and beneficial microorganisms in soilless cultures. Agron. Sustain. Dev. 2011. [CrossRef]

136. Neshev, G. Major soil-borne phytopathogens on tomato and cucumber in Bulgaria, and methods for their management. In Alternatives to Replace Methyl Bromide for Soil-Borne Pest Control in East and Central Europe; Labrada, R., Ed.; FAO, UNEP: Rome, Italy, 2008; pp. 1-14.

137. Engindeniz, S.; Gul, A. Economic analysis of soilless and soil-based greenhouse cucumber production in Turkey. Sci. Agric. 2008, 66, 606-614. [CrossRef]

138. Gruda, N. Does soilless culture have an influence on product quality of vegetables? J. Appl. Bot. Food Qual. 2009, 82, 141-147. 
139. Favrin, R.J.; Rahe, J.E.; Mauza, B. Pythium spp. associated with crown rot of cucumbers in British Columbia greenhouses. Plant Dis. 1988, 72, 683-687. [CrossRef]

140. Rafin, C.; Tirilly, Y. Characteristics and pathogenicity of Pythium spp. associated with root rot of tomatoes in soilless culture in Brittany, France. Plant Pathol. 1995, 44, 779-785. [CrossRef]

141. Hutton, D.G.; Forsberg, L.I. Phytophthora root rot in hydroponically grown lettuce. Australas. Plant Pathol. 1991, 20, 76-79. [CrossRef]

142. Gold, S.E.; Stanghellini, M.E. Effects of temperature on Pythium root rot of spinach grown under hydroponic conditions. Phytopathology 1985, 75, 333-337. [CrossRef]

143. Stanghellini, M.E.; Rasmussen, S.L. Hydroponics-A solution for zoosporic pathogens. Plant Dis. 1994, 78, 1129-1138. [CrossRef]

144. Chérif, M.; Tirilly, Y.; Bélanger, R.R. Effect of oxygen concentration on plant growth, lipidperoxidation, and receptivity of tomato roots to Pythium F under hydroponic conditions. Eur. J. Plant Pathol. 1997, 103, 264. [CrossRef]

145. Maucieri, C.; Nicoletto, C.; Os, E.; Anseeuw, D.; Havermaet, R.V.; Junge, R. Hydroponic technologies. In Aquaponics Food Production Systems; Goddek, S., Joyce, A., Kotzen, B., Burnell, G., Eds.; Springer: Cham, Switzerland, 2019; ISBN 978-3-030-15943-6. [CrossRef]

146. Labrada, R. Non-chemical alternatives to methyl bromide for soil-borne pest control. In Workshop on Non-Chemical Alternatives to Replace Methyl Bromide as a Soil Fumigant-Report; Labrada, R., Ed.; FAO/UNEP: Budapest, Hungary, 2007; pp. 3-14.

147. Budge, S.P.; Whipps, J.M. Potential for integrated control of Sclerotinia sclerotiorum in glasshouse lettuce using Coniothyrium minitans and reduced fungicide application. Phytopathology 2001, 91, 221-227. [CrossRef] [PubMed]

148. Matheron, M.E.; Porchas, M. Activity of boscalid, fenhexamid, fluazinam, fludioxonil, and vinclozolin on growth of Sclerotinia minor and S. sclerotiorum and development of lettuce drop. Plant Dis. 2004, 88, 665-668. [CrossRef] [PubMed]

149. Bubici, G.; Amenduni, M.; Colella, C.; D'amico, M.; Cirulli, M. Efficacy of acibenzolar-S-methyl and two strobilurins, azoxystrobin and trifloxystrobin, for the control of corky root of tomato and Verticillium wilt of eggplant. Crop Prot. 2006, 25, 814-820. [CrossRef]

150. Windels, C.E.; Brantner, J.R. Early-season application of azoxystrobin to sugarbeet for control of Rhizoctonia solani AG 4 and AG 2-2. J. Sugar Beet Res. 2005, 42, 1. [CrossRef]

151. Sundravadana, S.; Alice, D.; Kuttalam, S.; Samiyappan, R. Azoxystrobin activity on Rhizoctonia solani and its efficacy against rice sheath blight. Tunis. J. Plant Prot. 2007, 2, 79.

152. Marín, A.; Oliva, J.; Garcia, C.; Navarro, S.; Barba, A. Dissipation rates of cyprodinil and fludioxonil in lettuce and table grape in the field and under cold storage conditions. J. Agric. Food Chem. 2003, 51, 4708-4711. [CrossRef]

153. Benigni, M.; Bompeix, G. Chemical and biological control of Sclerotinia sclerotiorum in wilt of chicory culture. Pest Manag. Sci. 2010, 66, 1332-1336. [CrossRef]

154. Wang, M.C.; Gong, M.; Zang, H.B.; Hua, X.M.; Yao, J.; Pang, J.Y.; Yang, Y.H. Effect of methamidophos and urea application on microbial communities in soils as determined by microbial biomass and community level physiological profiles. J. Environ. Sci. Health Part B: Pestic. Food Contam. Agric. Wastes 2006, 41, $399-413$. [CrossRef] [PubMed]

155. Dekker, J. Build-up and persistence of fungicide resistance. In Rational Pesticide Use; Brent, K.J., Atkin, R.K., Eds.; Cambridge University Press: Cambridge, UK, 1987; pp. 153-168.

156. Mazzola, M.; Freilich, S. Prospects for biological soilborne disease control: Application of indigenous versus synthetic microbiomes. Phytopathology 2017, 107, 256-263. [CrossRef] [PubMed]

157. Loganathan, M.; Sible, G.V.; Maruthasalam, S.; Saravanakumar, D.; Raguchander, T.; Sivakumar, M.; Samiyappan, R. Trichoderma and chitin mixture based bioformulation for the management of head rot (Sclerotinia sclerotiorum (Lib.) de Bary)-root-knot (Meloidogyne incognita Kofoid and White; Chitwood) complex diseases of cabbage. Arch. Phytopathol. Plant Prot. 2010, 43, 1011-1024.

158. Kowsari, M.; Motallebi, M.; Zamani, R.M. Construction of new GFP-tagged fusants for Trichoderma harzianum with enhanced biocontrol activity. J. Plant Prot. Res. 2014, 54, 122-131. [CrossRef] 
159. Meyer, S.L.F.; Roberts, D.P.; Chitwood, D.J.; Carta, L.K.; Lumsden, R.D.; Mao, W. Application of Burkholderia cepacia and Trichoderma virens, alone and in combination, against Meloidogyne incognita on bell pepper. Nematropica 2001, 31, 75-86.

160. Dennis, C.; Webster, J. Antagonistic properties of species-groups of Trichoderma. I. Production of nonvolatile antibiotics. Trans. Br. Mycol. Soc. 1971, 57, 25-39. [CrossRef]

161. Dennis, C.; Webster, J. Antagonistic properties of species-groups of Trichoderma. II. Production of volatile antibiotics. Trans. Br. Mycol. Soc. 1971, 57, 41-48. [CrossRef]

162. Dennis, C.; Webster, J. Antagonistic properties of species-groups of Trichoderma. III. Hyphal interaction. Trans. Br. Mycol. Soc. 1971, 57, 363-369. [CrossRef]

163. Tomprefa, N.; Hill, R.; Whipps, J.; McQuilken, M. Some environmental factors affect growth and antibiotic production by mycoparasite Coniothyrium minitans. Biocontrol Sci. Technol. 2011, 21, 721-731. [CrossRef]

164. Smolińska, U.; Kowalska, B. Biological control of the soil-borne fungal pathogen Sclerotinia sclerotiorum-A review. J. Plant Pathol. 2018, 100, 1-12. [CrossRef]

165. Tu, J.C. Mycoparasitism by Coniothyrium minitans and its effects on sclerotia germination. J. Phytopathol. 1984, 109, 261-268. [CrossRef]

166. Bitsadze, N.; Siebold, M.; Koopmann, B.; von Tiedemann, A. Single and combined colonization of Sclerotinia sclerotiorum sclerotia by the fungal mycoparasites Coniothyrium minitans and Microsphaeropsis ochracea. Plant Pathol. 2015, 64, 690-700. [CrossRef]

167. Henis, Y.; Papavizas, G.C. Factrors affecting susceptibility of Sclerotium rolfsii sclerotia to Trichoderma harzianum in natural soil. (Abstr.). Phytopathology 1982, 72, 1010.

168. Henis, Y.; Papavizas, G.C. Factrors affecting germinability and susceptibility to attack of sclerotia of Sclerotium rolfsii by Trichoderma harzianum in field soil. Phytopathology 1983, 73, 1469-1474. [CrossRef]

169. Ji, S.H.; Paul, N.C.; Deng, J.X.; Kim, Y.S.; Yun, B.; Yu, S.H. Biocontrol activity of Bacillus amyloliquefaciens CNU114001 against fungal plant disease. Mycobiology 2013, 41, 234-242. [CrossRef] [PubMed]

170. Zhang, J.; Wang, J.D.; Liu, C.X.; Yuan, J.H.; Wang, X.J.; Xiang, W.S. A new prenylated indole derivative from endophytic actinobacteria Streptomyces sp. neau-D50. Nat. Prod. Res. 2014, 28, 431-437. [CrossRef] [PubMed]

171. Berta, G.; Sampo, S.; Gamalero, E.; Massa, N.; Lemanceau, P. Suppression of Rhizoctonia root-rot of tomato by Glomus mossae BEG12 and Pseudomonas fluorescens A6RI is associated with their effect on the pathogen growth and on the root morphogenesis. Eur. J. Plant Pathol. 2005, 111, 270-288. [CrossRef]

172. Pfleger, F.L.; Linderman, R.G. Mycorrhiza and Plant Growth; The American Phytopathological Society Press: St. Paul, MN, USA, 2000; p. 360.

173. Liu, R.J. Effect of vesicular-arbuscular mycorrhizal fungi on Verticillium wilt of cotton. Mycorrhiza 1995, 5, 293-297. [CrossRef]

174. Cordier, C.; Gianinazzi, S.; Gianinazzi-Pearson, V. Colonization patterns of root tissues by Phytophthora nicotianae var. parasitica related to reduced disease in mycorrhizal tomato. Plant Soil 1996, 185, 223-232.

175. Pertot, I.; Alabouvette, C.; Esteve, E.H.; Franca, S. Focus group in soil borne diseases: The use of microbial biocontrol agents against soilborne diseases. In EIP-AGRI Focus Group on Soil-Borne Diseases: Final Report; Claude, A., Clarkson, J., de Cara, F.M., de Caravalho Franca, S., Debode, J., Elorrieta, M., Furlan, L., Grand, A., Hinarejos Esteve, E., Kos, J., et al., Eds.; EIP-AGRI: Brussels, Belgium, 2015; pp. 3-5. [CrossRef]

176. Shafi, J.; Tian, H.; Ji, M. Bacillus species are versatile weapons for plant pathogens: A review. Biotechnol. Biotechnol. Equip. 2017, 31, 446-459.

177. Lan, X.; Zhang, J.; Zong, Z.; Ma, Q.; Wang, Y. Evaluation of the biocontrol potential of Purpureocillium lilacinum QLP12 against Verticillium dahliae in eggplant. Biomed Res. Int. 2017, 2, 1-8. [CrossRef]

178. Howell, C.R.; Stipanovic, R.D. Suppression of Pythium ultimum induced damping-off of cotton seedlings by Pseudomonas fluorescens and its antibiotic, pyoluterin. Phytopathology 1980, 70, 712-715. [CrossRef]

179. Chellemi, D.O.; Gamliel, A.; Katan, J.; Subbarao, K.V. Development and deployment of system-based approaches for the management of soilborne plant pathogens. Phytopathology 2016, 106, 216-225. [CrossRef] [PubMed]

180. Levins, R. Perspectives in integrated pest management: From and industrial to an ecological model of pest management. In Ecological Theory and Integrated Pest Management; Kogan, M., Ed.; John Wiley \& Sons: New York, NY, USA, 1986; pp. 1-18.

181. Lewis, W.J.; van Lenteren, J.C.; Phatak, S.C.; Tumlinson, J.H., III. A total system approach to sustainable pest management. Proc. Natl. Acad. Sci. USA 1997, 94, 12243-12248. [CrossRef] [PubMed] 
182. Colla, P.; Gilardi, G.; Gullino, M.L. A review and critical analysis of the european situation of soilborne disease management in the vegetable sector. Phytoparasitica 2012, 40, 515-523. [CrossRef]

183. Larkin, R.P. Soil health paradigms and implications for disease management. Annu. Rev. Phytopathol. 2015 53, 199-221. [CrossRef]

184. Newton, A.C.; Fitt, B.D.L.; Atkins, S.D.; Walters, D.R.; Daniell, T. Pathogenesis, mutualism and parasitism in the trophic space of microbe-plant interactions. Trends Microbiol. 2010, 18, 365-373. [CrossRef] 